\title{
Synthesis of a C21-C26 Segment of Superstolide A by Addition of a Chiral Allenylzinc Reagent to $(R)-N$-Boc Alaninal
}

James A. Marshall* and James J. Mulhearn

Department of Chemistry, P. O Box 400319 University of Virginia Charlottesville Virginia 22904

jam5x@virginia.edu

Supporting Information

Experimental Procedures for key intermediates

pp S1-S6

1H NMR Spectra for key intermediates

pp S7-S25 


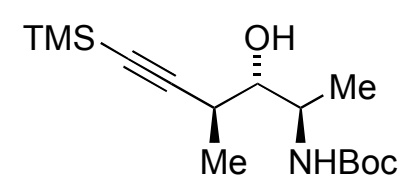

$(2 R, 3 S, 4 S)-(+)-2-($ tert-Butoxycarbonylamido)-4-methyl6-trimethylsilyl-5-hexyn-3-ol (5). To a solution of $(R)-N$-Boc alaninal $4(650 \mathrm{mg}, 3.75 \mathrm{mmol})$ in THF $(15 \mathrm{~mL})$ and HMPA $(5$

$\mathrm{mL}$ ) was added $\mathrm{Pd}(\mathrm{OAc})_{2}(42 \mathrm{mg}, 0.19 \mathrm{mmol})$ followed by $\mathrm{PPh}_{3}$ (49 mg, $0.19 \mathrm{mmol}$ ). Upon complete dissolution of the $\mathrm{PPh}_{3}$ the solution was cooled to 0 ${ }^{\circ} \mathrm{C}$. Pulverized InI beads $(1.36 \mathrm{~g}, 5.63 \mathrm{mmol})$ were added to the solution followed by $(R)$ TMSmesylate (R)-1 (1.00 g, $4.50 \mathrm{mmol})$. The solution was then stirred at $0{ }^{\circ} \mathrm{C}$ for $15 \mathrm{~min}$ before being warmed to rt. Upon completion of the reaction, as judged by TLC analysis, the reaction mixture was quenched with $10 \% \mathrm{HCl}(8 \mathrm{~mL})$ and diluted with $\mathrm{Et}_{2} \mathrm{O}$. The $\mathrm{Et}_{2} \mathrm{O}$ layer was separated, dried over $\mathrm{MgSO}_{4}$, and concentrated to give an oil that was chromatographed on silica gel with 10:1 hexanes/EtOAc as eluant to afford $775 \mathrm{mg}$ $(69 \%)$ of the anti,anti isomer 5: $[\propto]_{\mathrm{D}}{ }^{20}+24.5\left(c 0.5, \mathrm{CHCl}_{3}\right) ;{ }^{1} \mathrm{H}\left(300 \mathrm{MHz}, \mathrm{CDCl}_{3}\right) \partial$ 5.11 (br d, $J=7.6 \mathrm{~Hz}, 1 \mathrm{H}$ ), 3.84 (br s, $1 \mathrm{H}), 3.46$ (br s, $1 \mathrm{H}$ ), 2.60 (br t, $J=6.8 \mathrm{~Hz}, 1 \mathrm{H}$ ), $2.31(\mathrm{br} \mathrm{d}, J=4.8 \mathrm{~Hz}, 1 \mathrm{H}), 1.44(\mathrm{~s}, 9 \mathrm{H}), 1.20(\mathrm{~d}, J=7.0 \mathrm{~Hz}, 3 \mathrm{H}), 1.10(\mathrm{~d}, J=6.7 \mathrm{~Hz}$, $3 \mathrm{H}), 0.16$ (s, 9H); ${ }^{13} \mathrm{C} \mathrm{NMR}\left(125 \mathrm{MHz}, \mathrm{CDCl}_{3}\right) \partial 155.5,107.5,88.3,79.3,77.2,75.8$, $48.3,31.1,28.4,17.5,14.3,0.0$.

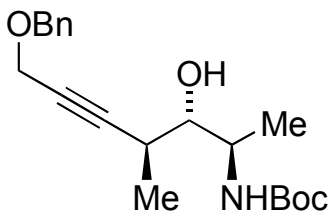

$(2 R, 3 S, 4 S)-(+)-2-($ tert-Butoxycarbonylamido)- 4-methyl7-benzyloxy-5-heptyn-3-ol (6). The above allenylindium procedure was followed with InI (210 $\mathrm{mg}, 0.87 \mathrm{mmol}),(R)-\mathrm{N}$-Boc alaninal $(100 \mathrm{mg}, 0.58 \mathrm{mmol}), \mathrm{Pd}(\mathrm{OAc})_{2}(7 \mathrm{mg}, 0.03 \mathrm{mmol}), \mathrm{PPh}_{3}$ ( $8 \mathrm{mg}, 0.03 \mathrm{mmol})$, and $(R)$-benzyloxy mesylate (R)-2 $(200 \mathrm{mg}$, $0.75 \mathrm{mmol})$ in THF $(3 \mathrm{~mL})$ and HMPA $(1 \mathrm{~mL})$ to afford $160 \mathrm{mg}(80 \%)$ of the anti,anti isomer 6 after chromatography on silica gel with $10: 1$ hexanes/EtOAc as eluant: $[\propto]_{\mathrm{D}}{ }^{20}$ $+14.9\left(c\right.$ 0.4 $\left.\mathrm{CHCl}_{3}\right) ;{ }^{1} \mathrm{H}$ NMR $\left(300 \mathrm{MHz}, \mathrm{CDCl}_{3}\right) \partial 7.35$ (s, $\left.5 \mathrm{H}\right), 5.00$ (br d, $J=1.9 \mathrm{~Hz}$, $1 \mathrm{H}), 4.58(\mathrm{~s}, 2 \mathrm{H}), 4.18$ and $4.19(2 \mathrm{~s}, 2 \mathrm{H}), 3.82(\mathrm{br} \mathrm{s}, 1 \mathrm{H}), 3.47(\mathrm{br} \mathrm{s}, 1 \mathrm{H}), 2.64(\mathrm{br} \mathrm{t}, J=$ $7.0 \mathrm{~Hz}, 1 \mathrm{H}), 2.32$ (br s, 1H), 1.44 (s, 9H), 1.23 (d, $J=7.0 \mathrm{~Hz}, 3 \mathrm{H}), 1.12$ (d, $J=6.8 \mathrm{~Hz}$, $3 \mathrm{H}) ;{ }^{13} \mathrm{C}$ NMR $\left(125 \mathrm{MHz}, \mathrm{CDCl}_{3}\right)$ d155.4, 137.4, 128.4, 128.1, 127.9, 87.6, 80.3, 79.3, $78.4,78.2,78.1,76.1,71.6,57.6,48.1,30.6,29.7,28.4,27.7,17.5,14.2$.

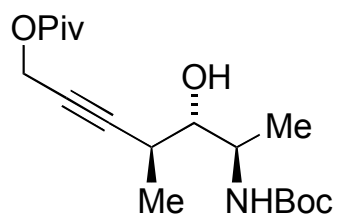

$(2 R, 3 S, 4 S)-(+)-2-($ tert-Butoxycarbonylamido)- 4-methyl7-pivaloxy-5-heptyn-3-ol (7). A. From the pivaloxyallenyl stannane and $\mathbf{I n B r 3}$. To a solution of $\mathrm{InBr}_{3}(1.80 \mathrm{~g}, 5.1 \mathrm{mmol})$ in EtOAc $(110 \mathrm{~mL})$ at $-78^{\circ} \mathrm{C}$ was added $(R)-N$-Boc alaninal $4(0.88 \mathrm{~g}$, $5.1 \mathrm{mmol})$ followed by the $(P)$-pivaloxyallenyl stannane $11(3.50 \mathrm{~g}$, $7.6 \mathrm{mmol})$. The solution was stirred at $-78^{\circ} \mathrm{C}$ for $10 \mathrm{~min}$, and then allowed to warm to rt. and stirred for an additional $1 \mathrm{~h}$. Upon completion of the reaction, as judged by TLC analysis, the reaction mixture was quenched with $10 \% \mathrm{HCl}$ and diluted with $\mathrm{Et}_{2} \mathrm{O}$. The $\mathrm{Et}_{2} \mathrm{O}$ layer was separated, dried over $\mathrm{MgSO}_{4}$, and stirred with $\mathrm{KF}$ on Celite for $20 \mathrm{~min}$. The resulting slurry was filtered through a pad of Celite, and concentrated to give an oil that was chromatographed on silica gel with 10:1 hexanes/EtOAc as eluant to afford 1.12 $\mathrm{g}(90 \%)$ of the anti,anti isomer 7: $[\propto]_{\mathrm{D}}{ }^{20}+20.4\left(c 1.0, \mathrm{CHCl}_{3}\right) ;{ }^{1} \mathrm{H}$ NMR $(300 \mathrm{MHz}$, $\mathrm{CDCl}_{3}$ ) д 4.96 (br d, $\left.J=6.8 \mathrm{~Hz}, 1 \mathrm{H}\right), 4.65(\mathrm{~d}, J=1.9 \mathrm{~Hz}, 2 \mathrm{H}), 3.79(\mathrm{br} \mathrm{s}, 1 \mathrm{H}), 3.47$ (br s, 
1H), 2.59 (br t $, J=6.0 \mathrm{~Hz}, 1 \mathrm{H}), 1.44(\mathrm{~s}, 9 \mathrm{H}), 1.21(\mathrm{~s}, 9 \mathrm{H}), 1.20(\mathrm{~d}, J=6.9 \mathrm{~Hz}, 3 \mathrm{H}), 1.10$ $(\mathrm{d}, J=6.8 \mathrm{~Hz}, 3 \mathrm{H}) ;{ }^{13} \mathrm{C} \mathrm{NMR}\left(125 \mathrm{MHz}, \mathrm{CDCl}_{3}\right)$ 2178.2, 155.7, 88.0, 79.5, 78.0, 76.7, $52.8,48.3,39.0,30.9,28.6,27.3,17.4,14.3$ and $0.32 \mathrm{~g}$ of the anti,syn isomer 10: $[\propto]_{\mathrm{D}}{ }^{20}$ +20.4 (c 1.0, $\left.\mathrm{CHCl}_{3}\right) ;{ }^{1} \mathrm{H}$ NMR $\left(300 \mathrm{MHz}, \mathrm{CDCl}_{3}\right) \partial 4.81$ (br s, $\left.1 \mathrm{H}\right), 4.69$ and $4.70(2 \mathrm{~s}$, 2H), 3.87 (br s, 1H), 3.31 (br s, 1H), 2.66 (br m, 2H), 1.47 (s, 9H), 1.25 (s, 12H), 0.96 (t, $J=8.0 \mathrm{~Hz}, 3 \mathrm{H}) ;{ }^{13} \mathrm{C} \mathrm{NMR}\left(125 \mathrm{MHz}, \mathrm{CDCl}_{3}\right) \partial \mathrm{177.9}, 156.0,87.8,79.3,77.6,52.6$, $47.2,38.7,30.8,29.7,28.3,27.0,26.8,26.3,18.9,17.3,16.9,13.6$.

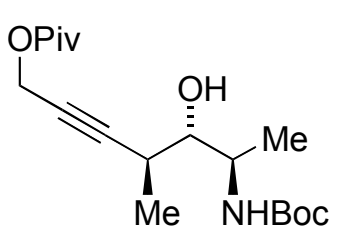

B. From the Pivaloxy Mesylate and $\mathbf{E t}_{\mathbf{2}} \mathbf{Z n}$. To a solution of $\mathrm{Pd}(\mathrm{OAc})_{2}(47 \mathrm{mg}, 0.21 \mathrm{mmol})$ in $\mathrm{THF}(55 \mathrm{~mL})$ at $-78{ }^{\circ} \mathrm{C}$ was added $\mathrm{PPh}_{3}(55 \mathrm{mg}, 0.21 \mathrm{mmol}$ ) followed by the $(R)$-pivaloxy mesylate $(1.66 \mathrm{~g}, 6.35 \mathrm{mmol})$ and $(R)-N$-Boc alaninal $4(730 \mathrm{mg}$,

$4.23 \mathrm{mmol})$. The solution was stirred at $-78{ }^{\circ} \mathrm{C}$ for $5 \mathrm{~min}$., after which $\mathrm{Et}_{2} \mathrm{Zn}(12 \mathrm{~mL}, 1 \mathrm{M}$ in hexane, $12 \mathrm{mmol})$ was added dropwise. The resulting solution was allowed to warm to $-20{ }^{\circ} \mathrm{C}$, and stirred for $40 \mathrm{~h}$. Upon completion of the reaction, as judged by TLC analysis, the reaction mixture was poured into a rapidly stirred mixture of $\mathrm{Et}_{2} \mathrm{O}(25 \mathrm{~mL})$ and sat. aq. $\mathrm{NH}_{4} \mathrm{Cl}(50 \mathrm{~mL})$. The mixture was allowed to warm to rt. and stirred vigorously for $30 \mathrm{~min}$. The $\mathrm{Et}_{2} \mathrm{O}$ layer was separated, washed with brine, dried over $\mathrm{MgSO}_{4}$, filtered, and concentrated to give an oil that was chromatographed on silica gel with $8: 1$ hexane/EtOAc as eluant to afford $1.13 \mathrm{~g}(78 \%)$ of the anti,anti diastereomer 7.

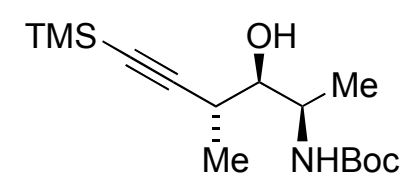

$(2 R, 3 R, 4 R)-(+)-2-($ tert-Butoxycarbonylamido)-4-methyl6-trimethylsilyl-5-hexyn-3-ol (8). The standard allenyl indium procedure was followed with InI $(273 \mathrm{mg}, 1.13 \mathrm{mmol}),(R)-N$ Boc alaninal $(130 \mathrm{mg}, 0.75 \mathrm{mmol}), \mathrm{Pd}(\mathrm{OAc})_{2}(8 \mathrm{mg}, 0.04$ $\mathrm{mmol}), \mathrm{PPh}_{3}(10 \mathrm{mg}, 0.04 \mathrm{mmol})$, and $(S)$-TMSmesylate $(200 \mathrm{mg}, 0.90 \mathrm{mmol})$ in THF (3 $\mathrm{mL})$ and HMPA $(\mathrm{mL})$ to afford $166 \mathrm{mg}(74 \%)$ of the anti,syn isomer after chromatography on silica gel with 10:1 hexanes/EtOAc as eluant: $[\propto]_{\mathrm{D}}{ }^{20}+68.5(c 1.0$, $\left.\mathrm{CHCl}_{3}\right) ;{ }^{1} \mathrm{H}\left(300 \mathrm{MHz}, \mathrm{CDCl}_{3}\right)$ d 4.77 (br s, $\left.1 \mathrm{H}\right), 3.84$ (br s, $\left.1 \mathrm{H}\right), 3.23$ and $3.25(2 \mathrm{~d}, J=$ $2.7 \mathrm{~Hz}, 1 \mathrm{H}), 2.63$ (q, $J=7.4 \mathrm{~Hz}, 1 \mathrm{H} 0,1.43$ (s, 9H), 1.214 (t, $J=7.2 \mathrm{~Hz}, 6 \mathrm{H}), 0.16$ (s, $9 \mathrm{H}) ;{ }^{13} \mathrm{C}$ NMR $\left(125 \mathrm{MHz}, \mathrm{CDCl}_{3}\right)$ 2155.8, 107.6, 87.9, 79.2, 76.2, 46.6, 31.7, 28.4, 19.1, $17.0,0.1$.

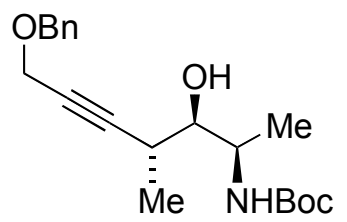

$(2 R, 3 R, 4 R)-(+)-2-($ tert-Butoxycarbonylamido)- 4-methyl7-benzyloxy-5-heptyn-3-ol (9). The standard allenyl indium procedure was followed with InI (210 $\mathrm{mg}, 0.87 \mathrm{mmol}),(S)-N$-Boc alaninal (100 mg, $0.58 \mathrm{mmol}), \mathrm{Pd}(\mathrm{OAc})_{2}(7 \mathrm{mg}, 0.03 \mathrm{mmol}), \mathrm{PPh}_{3}$ (8 $\mathrm{mg}, 0.03 \mathrm{mmol})$, and $(S)$-benzyloxy mesylate (S)-2 (186 mg, 0.70 $\mathrm{mmol})$ in THF $(3 \mathrm{~mL})$ and HMPA $(\mathrm{mL})$ to afford $165 \mathrm{mg}$ of the anti,syn isomer 9 and 15 $\mathrm{mg}$ of the anti,anti isomer $\mathbf{6}$ after chromatography on silica gel with 10:1 hexanes/EtOAc as eluant. Anti,syn: $[\propto]_{\mathrm{D}}{ }^{20}+31\left(c 1.0, \mathrm{CHCl}_{3}\right)$, and $15 \mathrm{mg}$ of the anti,anti isomer: $[\propto]_{\mathrm{D}}{ }^{20}$ +31.0 (c 1.0, $\left.\mathrm{CHCl}_{3}\right) ;{ }^{1} \mathrm{H} \mathrm{NMR}\left(500 \mathrm{MHz}, \mathrm{CDCl}_{3}\right) \partial 7.35$ (d, J=4.8 Hz, 5H), 4.74 (br s, $1 \mathrm{H}), 4.59$ (s, 2H), 4.19 (s, 2H), 3.86 (br s, 1H), 3.26 (br m, 1H), 2.67 (br t, $J=5.8 \mathrm{~Hz}$, $1 \mathrm{H}), 1.51-1.70(\mathrm{br} \mathrm{s}, 1 \mathrm{H}), 1.44(\mathrm{~s}, 9 \mathrm{H}), 1.25(\mathrm{~d}, J=6.9 \mathrm{~Hz}, 3 \mathrm{H}), 1.22(\mathrm{~d}, J=6.8 \mathrm{~Hz}, 3 \mathrm{H})$. 


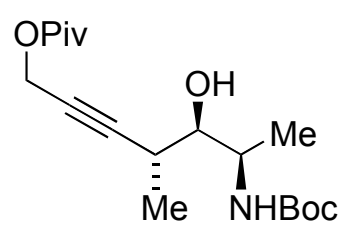

$(2 R, 3 R, 4 R)-(+)-2-($ tert-Butoxycarbonylamido)- 4-methyl-

7-pivaloxy-5-heptyn-3-ol (10). The standard allenyl zinc procedure was followed with $\mathrm{Et}_{2} \mathrm{Zn}(2.9 \mathrm{~mL}, 1 \mathrm{M}$ in hexane, $2.9 \mathrm{mmol}),(R)-\mathrm{N}$ Boc alaninal 4 (250 mg, $1.44 \mathrm{mmol}),(S)$-pivyloxy mesylate (S)-3

(570 mg, $2.17 \mathrm{mmol}), \mathrm{Pd}(\mathrm{OAc})_{2}(16 \mathrm{mg}, 0.072 \mathrm{mmol})$, and $\mathrm{PPh}_{3}(19$ $\mathrm{mg}, 0.072 \mathrm{mmol})$ in THF $(15 \mathrm{~mL})$ for $56 \mathrm{~h}$ to afford $245 \mathrm{mg}(50 \%)$ of the anti,syn isomer 10 after chromatography on silica gel with 10:1 hexane/EtOAc as eluant.

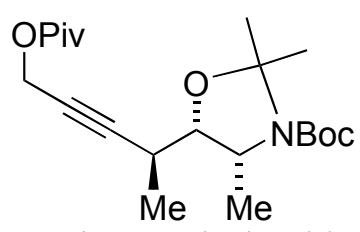

$(2 R, 3 S, 4 S)-(+)-2-($ tert-Butoxycarbonylamido)-4-methyl7-pivaloxy-5-heptyn-3-ol 2,3 Acetonide (12). To a solution of alcohol $7(590 \mathrm{mg}, 1.70 \mathrm{mmol})$ in 2,2-dimethoxypropane $(10 \mathrm{~mL})$ at $\mathrm{rt}$. was added p-toluenesulfonic acid $(32 \mathrm{mg}, 0.17 \mathrm{mmol})$. The solution was stirred at rt. for $12 \mathrm{~h}$. Upon completion of the reaction, as judged by TLC analysis, the reaction mixture was concentrated to give an oil that was chromatographed on silica gel with 19:1 hexanes/EtOAc as eluant to afford 830 $\mathrm{mg}(100 \%)$ of the acetonide 12: $[\propto]_{\mathrm{D}}{ }^{20}+5.4\left(c 1.0, \mathrm{CH}_{2} \mathrm{Cl}_{2}\right) ;{ }^{1} \mathrm{H}$ NMR $\left(300 \mathrm{MHz}, \mathrm{CDCl}_{3}\right)$ d $4.68(\mathrm{~s}, 2 \mathrm{H}), 4.93$ (br t, $J=5.7 \mathrm{~Hz}, 0.5 \mathrm{H}), 3.77(\mathrm{~m}, 1.5 \mathrm{H}), 2.60$ (br t, $J=7.3 \mathrm{~Hz}, 1 \mathrm{H})$, $1.50(2 \mathrm{~d}, J=10.8 \mathrm{~Hz}, 6 \mathrm{H}), 1.41(\mathrm{~d}, J=9.5 \mathrm{~Hz}, 9 \mathrm{H}), 1.15(\mathrm{~d}, J=0.9 \mathrm{~Hz}, 9 \mathrm{H}), 1.11(\mathrm{t}, J$ $=7.9 \mathrm{~Hz}, 3 \mathrm{H}), 1.05(2 \mathrm{~d}, J=6.3$ and $5.6 \mathrm{~Hz}, 3 \mathrm{H}) ;{ }^{13} \mathrm{C}\left(125 \mathrm{MHz}, \mathrm{CDCl}_{3}\right) \partial 177.9,151.9$, $151.5,93.3,92.9,88.2,88.2,80.2,79.6,79.4,79.3,76.0,75.9,54.7,52.9,38.8,28.7$, $28.6,28.3,27.4,27.2,26.5,26.4,25.1,24.0,17.5,17.4,14.1,13.3$.

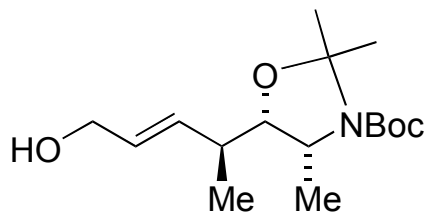

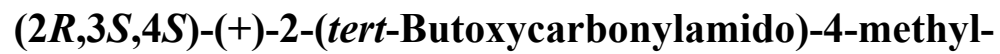
5-heptene-3,7-diol Acetonide (13). To a solution of acetonide $12(2.5 \mathrm{~g}, 6.6 \mathrm{mmol})$ in $\mathrm{THF}(130 \mathrm{~mL})$ at $0{ }^{\circ} \mathrm{C}$ was added Red-Al (3.3 M solution in toluene, $20 \mathrm{~mL}, 66.0 \mathrm{mmol}$ ). The solution was stirred at $0{ }^{\circ} \mathrm{C}$ for $12 \mathrm{~h}$. Upon completion of the reaction, as judged by TLC analysis, the reaction mixture was poured into a rapidly stirred mixture of $\mathrm{Et}_{2} \mathrm{O}(300 \mathrm{~mL})$ and sat. aq. $\mathrm{NH}_{4} \mathrm{Cl}(600 \mathrm{~mL})$. The mixture was allowed to warm to rt. and stirred vigorously for $30 \mathrm{~min}$. $\mathrm{The} \mathrm{Et}_{2} \mathrm{O}$ layer was separated, dried over $\mathrm{MgSO}_{4}$, filtered, and concentrated to give an oil that was chromatographed on silica gel with 4:1 hexanes/EtOAc as eluant to afford $1.97 \mathrm{~g}(85 \%)$ of allylic alcohol 13: $[\propto]_{\mathrm{D}}{ }^{20}$ $+2.0\left(\right.$ c 1.0, $\left.\mathrm{CHCl}_{3}\right) ;{ }^{1} \mathrm{H}$ NMR $\left(500 \mathrm{MHz}, \mathrm{DMSO}, 98{ }^{\circ} \mathrm{C}\right) \partial 5.87(\mathrm{~m}, 2 \mathrm{H}), 4.52(\mathrm{br} \mathrm{s}$, $0.5 \mathrm{H}), 4.17(\mathrm{~d}, J=4.7 \mathrm{~Hz}, 2 \mathrm{H}), 4.10(\mathrm{br} \mathrm{s}, 0.5 \mathrm{H}), 3.94(\mathrm{dd}, J=2.5 \mathrm{~Hz}, 1 \mathrm{H}), 3.26(\mathrm{~s}, 1 \mathrm{H})$, $2.74(\mathrm{~s}, 1 \mathrm{H}), 1.73(\mathrm{~s}, 6 \mathrm{H}), 1.68(\mathrm{~s}, 9 \mathrm{H}), 1.32(\mathrm{~d}, J=6.3 \mathrm{~Hz}, 3 \mathrm{H}), 1.18(\mathrm{~d}, J=6.7 \mathrm{~Hz}, 3 \mathrm{H})$; ${ }^{13} \mathrm{C}$ NMR $\left(125 \mathrm{MHz}, \mathrm{CDCl}_{3}\right.$ ) $\partial 151.9,151.5,135.0,128.1,129.0,93.1,92.7,80.5,80.3$, $80.2,79.5,63.9,54.9,35.5,35.4,28.8,28.7,28.4,27.525 .2,24.1,16.7,16.7,14.2,13.5$.

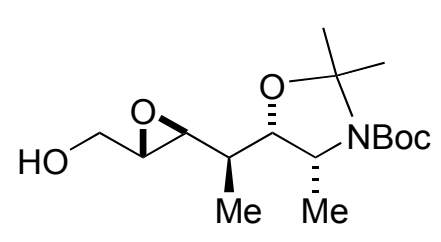

$(2 R, 3 S, 4 S, 5 S, 6 R)-(-)-2-($ tert-Butoxycarbonylamido)4-methyl-5,6-epoxy-3,7-heptanediol 2,3 Acetonide (14). To a solution of $4 \mathrm{~A}$ MS in $\mathrm{CH}_{2} \mathrm{Cl}_{2}(10 \mathrm{~mL})$ at $-20{ }^{\circ} \mathrm{C}$ was added $\mathrm{Ti}\left(\mathrm{O} i \mathrm{Pr}_{4}\right)(387 \mathrm{mg}, 1.37 \mathrm{mmol})$ and L-(+)-DET $(339 \mathrm{mg}, 1.64$ $\mathrm{mmol})$. After $5 \mathrm{~min}, t$-BuOOH (5-6 M solution in decane, 0.55 
$\mathrm{mL}, 2.74 \mathrm{mmol}$ ) was added. After $20 \mathrm{~min}$, allylic alcohol 13 (410 mg, $1.37 \mathrm{mmol})$ was added. Upon completion of the reaction, as judged by TLC analysis, the reaction mixture was quenched with $\mathrm{H}_{2} \mathrm{O}(0.55 \mathrm{~mL})$, and allowed to warm to rt. The slurry was filtered through a pad of Celite and the resulting solution was poured into a $30 \%$ aqueous solution of $\mathrm{NaOH}$ in brine $(2 \mathrm{~mL})$ and stirred vigorously for $30 \mathrm{~min}$. The $\mathrm{CH}_{2} \mathrm{Cl}_{2}$ layer was separated, dried over $\mathrm{MgSO}_{4}$, filtered, and concentrated to give an oil that was chromatographed on silica gel with $4: 1$ hexanes/EtOAc as eluant to afford $380 \mathrm{mg}(85 \%)$ of epoxide 14: $[\propto]_{\mathrm{D}}{ }^{20}-7.6\left(c 1.0, \mathrm{CHCl}_{3}\right) ;{ }^{1} \mathrm{H} \mathrm{NMR}\left(300 \mathrm{MHz}, \mathrm{CDCl}_{3}\right) \partial 4.07$ (br t, $J=$ $6.0 \mathrm{~Hz}, 0.5 \mathrm{H}$ ), 3.86 (br m, 2.5 H), 3.71 (br m, 1H), 3.11 (s, 1H), 2.97 (d, $J=6.8 \mathrm{~Hz}, 1 \mathrm{H})$, 1.78 (br s, $1 \mathrm{H}), 1.70$ (br m, 1H), 1.53 and $1.59(2 \mathrm{~d}, J=6.3 \mathrm{~Hz}, 6 \mathrm{H}), 1.51(\mathrm{~d}, J=4.7 \mathrm{~Hz}$, $9 \mathrm{H}), 1.12(2 \mathrm{~d}, J=6.3$ and $3.0 \mathrm{~Hz}, 3 \mathrm{H}), 1.00(\mathrm{t}, J=5.8 \mathrm{~Hz}, 3 \mathrm{H}) ;{ }^{13} \mathrm{C} \mathrm{NMR}(125 \mathrm{MHz}$, $\left.\mathrm{CDCl}_{3}\right)$ d152.1, 151.7, 93.2, 92.8, 92.3, 80.3, 79.6, 78.6, 78.4, 62.1, 58.6, 58.5, 54.8, 35.5, $35.4,28.7,28.5,27.6,25.5,24.3,14.3,13.6,12.7$.

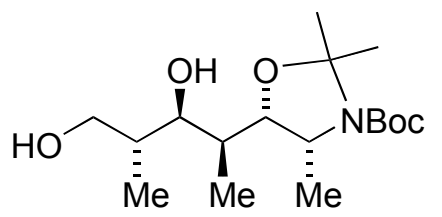

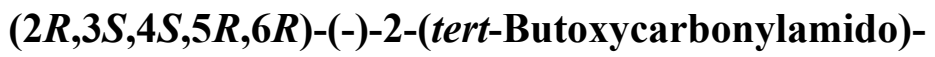
4,6-dimethylheptane-3,5,7-triol Acetonide (15). To a solution of $\mathrm{CuCN}(568 \mathrm{mg}, 6.35 \mathrm{mmol})$ in THF $(0.2 \mathrm{~mL})$ at $-78{ }^{\circ} \mathrm{C}$ was added MeLi (1.6 M solution in $\mathrm{Et}_{2} \mathrm{O}, 7.9 \mathrm{~mL}$, $12.70 \mathrm{mmol})$. The solution was allowed to warm to $0{ }^{\circ} \mathrm{C}$ and stirred for $30 \mathrm{~min}$. Epoxide 14 was added dropwise, and the solution was stirred for an additional $36 \mathrm{~h}$. Upon completion of the reaction, as judged by TLC analysis, the reaction mixture was poured into a rapidly stirred mixture of $\mathrm{Et}_{2} \mathrm{O}(50 \mathrm{~mL})$ and a 9:1 mixture of sat. aq. $\mathrm{NH}_{4} \mathrm{Cl} / \mathrm{NH}_{4} \mathrm{OH}(100 \mathrm{~mL})$. The mixture was allowed to warm to rt. and stirred vigorously for $30 \mathrm{~min}$. The $\mathrm{Et}_{2} \mathrm{O}$ layer was separated, dried over $\mathrm{MgSO}_{4}$, filtered, and concentrated to give an oil that was chromatographed on silica gel with $4: 1$ hexanes/EtOAc as eluant to afford $103 \mathrm{mg}(98 \%)$ of diol 15: $\propto \propto]_{\mathrm{D}}{ }^{20}-11.5\left(c 1.0, \mathrm{CHCl}_{3}\right)$; ${ }^{1} \mathrm{H}$ NMR (300 MHz, $\mathrm{CDCl}_{3}$ ) $\partial 4.06$ (br t, $J=5.3 \mathrm{~Hz}, 0.5 \mathrm{H}$ ), 3.95 (br m, 2.5H), 3.75 (br s, 2H), 2.05-2.24 (br s, 2H), 1.86-1.94 (br s, 2H), 1.53 and $1.58(2 \mathrm{~d}, J=5.9 \mathrm{~Hz}, 6 \mathrm{H}), 1.50$ and $1.51(2 \mathrm{~s}, 9 \mathrm{H}), 1.12$ and $1.15(2 \mathrm{~d}, J=6.4 \mathrm{~Hz}, 3 \mathrm{H}), 0.88(\mathrm{~m}, 6 \mathrm{H})$.

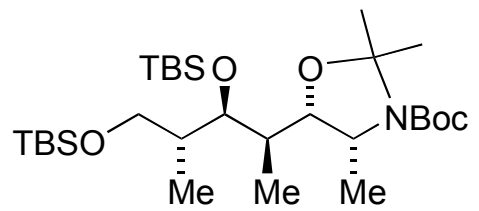

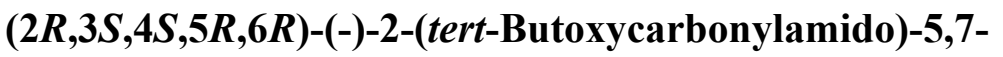
[(tert-Butyldimethylsilyl)oxy]-4,6-dimethylheptane-3-ol Acetonide (16). To a solution of diol $15(510 \mathrm{mg}, 1.54$ mmol $)$ in $\mathrm{CH}_{2} \mathrm{Cl}_{2}(10 \mathrm{~mL})$ at $0{ }^{\circ} \mathrm{C}$ was added 2,6-lutidene (0.71 mL, $6.14 \mathrm{mmol})$ followed by TBSOTf (890 mg, 3.38 mmol). After $10 \mathrm{~min}$, the solution was allowed to warm to rt. Upon completion of the reaction, as judged by TLC analysis, the reaction was quenched with $\mathrm{NaHCO}_{3}$ and extracted with $\mathrm{Et}_{2} \mathrm{O}$. The $\mathrm{Et}_{2} \mathrm{O}$ layer was separated, dried over $\mathrm{MgSO}_{4}$, filtered, and concentrated to give an oil that was chromatographed on silica gel with 19:1 hexanes/EtOAc as eluant to afford $730 \mathrm{mg}(85 \%)$ of bis-silyl ether 16: $[\propto]_{\mathrm{D}}{ }^{20}-1.2$ (c 1.0, $\left.\mathrm{CHCl}_{3}\right) ;{ }^{1} \mathrm{H}$ NMR $\left(300 \mathrm{MHz}, \mathrm{CDCl}_{3}\right), \partial 4.08(\mathrm{~m}, 1 \mathrm{H}), 3.98$ (br t, $\left.J=4.7 \mathrm{~Hz}, 0.5 \mathrm{H}\right), 3.79$ $(\mathrm{m}, 1.5 \mathrm{H}), 3.63(\mathrm{~m}, 1 \mathrm{H}), 3.39(\mathrm{~m}, 1 \mathrm{H}), 1.79(\mathrm{br} \mathrm{m}, 2 \mathrm{H}), 1.50$ and $1.53(2 \mathrm{~d}, J=4.8 \mathrm{~Hz}$, $6 \mathrm{H}), 1.46$ and $1.47(2 \mathrm{~s}, 9 \mathrm{H}), 1.06$ and $1.10(2 \mathrm{~d}, J=6.1 \mathrm{~Hz}, 3 \mathrm{H}), 0.95(\mathrm{~d}, J=3.6 \mathrm{~Hz}$, $3 \mathrm{H}), 0.89(\mathrm{~s}, 18 \mathrm{H}), 0.79$ and $0.81(2 \mathrm{~d}, J=3.6 \mathrm{~Hz}, 3 \mathrm{H}), 0.48$ and $0.61(2 \mathrm{~s}, 12 \mathrm{H}) ;{ }^{13} \mathrm{C}$ NMR (125 MHz, $\left.\mathrm{CDCl}_{3}\right)$ 2152.1, 151.7, 93.0, 92.5, 79.9, 79.3, 77.8, 77.4, 71.2, 65.9, 
$55.0,42.2,35.0,34.9,28.8,28.7,28.6,27.7,26.4,26.2,26.0,24.8,18.7,18.5,14.1,13.6$, $13.5,10.4,10.2,-3.7,-4.0,-5.1$.

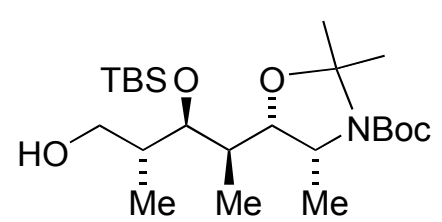

$(2 R, 3 S, 4 S, 5 R, 6 R)-(-)-2-($ tert-Butoxycarbonylamido)-5-[(tertButyldimethylsilyl)oxy]-4,6-dimethylheptane-3,7-diol 2,3 Acetonide (17). To a solution of bis-silyl ether $16(20 \mathrm{mg}, 0.04$ $\mathrm{mmol})$ in $\mathrm{MeOH}(2 \mathrm{~mL})$ at $0{ }^{\circ} \mathrm{C}$ was added $\mathrm{HCl}(0.05 \mathrm{~mL})$. Upon completion of the reaction, as judged by TLC analysis, the reaction was quenched with $\mathrm{NaHCO}_{3}(0.5 \mathrm{~mL})$ and extracted with $\mathrm{Et}_{2} \mathrm{O}$. The $\mathrm{Et}_{2} \mathrm{O}$ layer was separated, dried over $\mathrm{MgSO}_{4}$, filtered, and concentrated to give an oil that was chromatographed on silica gel with 3:1 hexanes/EtOAc as eluant to afford $15 \mathrm{mg}(94 \%)$ of alcohol 17: $[\propto]_{\mathrm{D}}{ }^{20}-0.7\left(c 1.0, \mathrm{CHCl}_{3}\right) ;{ }^{1} \mathrm{H} \mathrm{NMR}\left(300 \mathrm{MHz}, \mathrm{CDCl}_{3}\right) \partial 4.15$ (br t, $J=$ $6.6 \mathrm{~Hz}, 1 \mathrm{H}), 4.06$ (br t, $J=4.8 \mathrm{~Hz}, 0.5 \mathrm{H}), 3.85(\mathrm{~m}, 1.5 \mathrm{H}), 3.58(\mathrm{~d}, J=6.6 \mathrm{~Hz}, 2 \mathrm{H}), 1.85-$ 1.99 (br m, 3H), 1.55 and $1.60(2 \mathrm{~d}, J=7.3 \mathrm{~Hz}, 6 \mathrm{H}), 1.51$ and $1.53(2 \mathrm{~s}, 9 \mathrm{H}), 1.14$ and $1.18(2 \mathrm{~d}, J=6.3 \mathrm{~Hz}, 3 \mathrm{H}), 0.95$ and $0.96(2 \mathrm{~s}, 9 \mathrm{H}), 0.95(\mathrm{~d}, J=5.5 \mathrm{~Hz}, 3 \mathrm{H}), 0.90(\mathrm{~d}, J=$ $5.2 \mathrm{~Hz}, 3 \mathrm{H}), 0.13(\mathrm{~m}, 6 \mathrm{H})$.

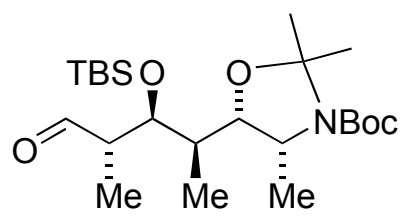

(2R,3R,4S,5S,6R)-(+)-6-(tert-Butoxycarbonylamido)-3[(tert-Butyldimethylsilyl)oxy]-2,4-dimethyl-5-hydroxyheptanal Acetonide (18). To a solution of alcohol 17 (80 $\mathrm{mg}, 0.18 \mathrm{mmol})$ in $\mathrm{CH}_{2} \mathrm{Cl}_{2}(0.75 \mathrm{~mL})$ was added Dess-Martin reagent $(115 \mathrm{mg}, 0.27 \mathrm{mmol})$. Upon completion of the reaction, as judged by TLC analysis, the reaction was quenched with $\mathrm{Na}_{2} \mathrm{~S}_{2} \mathrm{O}_{3}$ and extracted with $\mathrm{Et}_{2} \mathrm{O}$. The $\mathrm{Et}_{2} \mathrm{O}$ layer was separated, washed with brine, dried over $\mathrm{MgSO}_{4}$, filtered, and concentrated to give an oil that was chromatographed on silica gel with 9:1 hexanes/EtOAc as eluant to afford $72 \mathrm{mg}(90 \%)$ of aldehyde 18: $[\propto]_{\mathrm{D}}{ }^{20}+15.6(c$ $\left.0.5, \mathrm{CHCl}_{3}\right) ;{ }^{1} \mathrm{H}$ NMR $\left(300 \mathrm{MHz}, \mathrm{CDCl}_{3}\right) 29.73$ and $9.74(2 \mathrm{~s}, 1 \mathrm{H}), 4.33(\mathrm{dd}, J=6.0 \mathrm{~Hz}$, $1 \mathrm{H}), 3.98-4.02(\mathrm{~m}, 0.5 \mathrm{H}), 3.76-3.85(\mathrm{~m}, 1.5 \mathrm{H}), 2.53-2.58(\mathrm{~m}, 1 \mathrm{H}), 1.71-1.79(\mathrm{~m}, 1 \mathrm{H})$, 1.50 and $1.56(2 \mathrm{~d}, J=5.7 \mathrm{~Hz}, 6 \mathrm{H}), 1.46$ and $1.47(2 \mathrm{~s}, 9 \mathrm{H}), 1.09$ and $1.11(2 \mathrm{~d}, J=5.5$ $\mathrm{Hz}, 3 \mathrm{H}), 0.88(\mathrm{~s}, 9 \mathrm{H}), 0.85$ and $0.87(2 \mathrm{~d}, J=6.9 \mathrm{~Hz}, 3 \mathrm{H}), 0.06$ and $0.08(2 \mathrm{~d}, J=5.0 \mathrm{~Hz}$, $6 \mathrm{H}) ;{ }^{13} \mathrm{C}$ NMR $\left(125 \mathrm{MHz}, \mathrm{CDCl}_{3}\right) \partial 207.6,208.0,151.7,152.0,92.9,93.4,79.6,80.2$, $77.5,72.3,72.4,55.1,55.1,52.5,52.6,36.7,36.9,28.7,28.8,27.7,28.61,26.3,24.8$, $25.9,18.6,13.5,14.1,10.4,11.5,-3.76$.

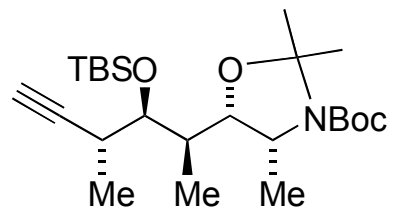

$(2 R, 3 S, 4 S, 5 R, 6 R)-(-)-2-($ tert-Butoxycarbonylamido)-5-[(tertButyldimethylsilyl)oxy]-4,6-dimethyl-7-heptyn-3-ol

Acetonide (19). To a solution of $\mathrm{KOtBu}(32 \mu \mathrm{L}, 1 \mathrm{M}$ in THF, $32 \mu \mathrm{mol})$ in THF $(60 \mu \mathrm{L})$ at $-78{ }^{\circ} \mathrm{C}$ was added dimethyl (diazomethyl)phosphonate $(5 \mathrm{mg}, 34 \mu \mathrm{mol})$ in THF $(90 \mu \mathrm{L})$. The solution was stirred at $-78{ }^{\circ} \mathrm{C}$ for $5 \mathrm{~min}$, and then aldehyde $18(10 \mathrm{mg}, 23 \mu \mathrm{mol})$ in THF $(35 \mu \mathrm{L})$ was added. Upon completion of the reaction, as judged by TLC analysis, the reaction was quenched with $\mathrm{NH}_{4} \mathrm{Cl}$ and extracted with $\mathrm{Et}_{2} \mathrm{O}$. The $\mathrm{Et}_{2} \mathrm{O}$ layer was separated, dried over $\mathrm{MgSO}_{4}$, filtered, and concentrated to give an oil that was chromatographed on silica gel with 19:1 n-pentane/EtOAc as eluant to afford $8 \mathrm{mg}(81 \%)$ of alkyne 19: $\propto \propto]_{\mathrm{D}}{ }^{20}-1.0(c 0.2$, $\left.\mathrm{CH}_{2} \mathrm{Cl}_{2}\right) ;{ }^{1} \mathrm{H}$ NMR $\left(300 \mathrm{MHz}, \mathrm{CDCl}_{3}\right) 24.11(\mathrm{dd}, J=6.0 \mathrm{~Hz}, 1 \mathrm{H}), 3.97-4.01(\mathrm{~m}, 0.5 \mathrm{H})$, $3.75-3.85(\mathrm{~m}, 1.5 \mathrm{H}), 2.60-2.63(\mathrm{~m}, 1 \mathrm{H}), 2.07$ and $2.08(2 \mathrm{~s}, 1 \mathrm{H}), 1.98-2.01(\mathrm{~m}, 1 \mathrm{H}), 1.51$ 
and $1.50(2 \mathrm{~d}, J=3.3 \mathrm{~Hz}, 6 \mathrm{H}), 1.47$ and $1.48(2 \mathrm{~s}, 9 \mathrm{H}), 1.20$ and $1.22(2 \mathrm{~d}, J=2.9 \mathrm{~Hz}$, $3 \mathrm{H}), 1.08$ and $1.12(2 \mathrm{~d}, J=6.2 \mathrm{~Hz}, 3 \mathrm{H}), 0.91(\mathrm{~s}, 9 \mathrm{H}), 0.85$ and $0.87(\mathrm{~s} \mathrm{~d}, J=5.0 \mathrm{~Hz}, 3 \mathrm{H})$, 0.07 and 0.09 (s d, $J=4.0 \mathrm{~Hz}, 6 \mathrm{H})$.

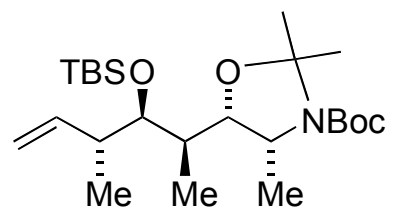

$(2 R, 3 S, 4 S, 5 R, 6 R)-(+)-2-($ tert-Butoxycarbonylamido)-5-[(tertButyldimethylsilyl)oxy]-4,6-dimethyl-7-hepten-3-ol Acetonide (20). To a solution of $\mathrm{MePh}_{3} \mathrm{PBr}(96.5 \mathrm{mg}, 0.271$ $\mathrm{mmol})$ in THF $(0.5 \mathrm{~mL})$ was added BuLi $(0.11 \mathrm{~mL}, 2.5 \mathrm{M}$ in hexanes, $0.275 \mathrm{mmol})$ at $0{ }^{\circ} \mathrm{C}$. The solution was cooled to -78 ${ }^{\circ} \mathrm{C}$, after which aldehyde $18(20 \mathrm{mg}, 0.045 \mathrm{mmol})$ was added. The solution was then stirred at $-78{ }^{\circ} \mathrm{C}$ before being warmed to rt. Upon completion of the reaction, as judged by TLC analysis, the reaction was quenched with $\mathrm{NH}_{4} \mathrm{Cl}$ and extracted with $\mathrm{Et}_{2} \mathrm{O}$. The $\mathrm{Et}_{2} \mathrm{O}$ layer was separated, dried over $\mathrm{MgSO}_{4}$, filtered, and concentrated to give an oil that was chromatographed on silica gel with 19:1 hexanes/EtOAc as eluant to afford $20 \mathrm{mg}$ of alkene 19 contaminated with triphenylphosphine : $[\propto]_{\mathrm{D}}{ }^{20}+3.6\left(c 1.0, \mathrm{CH}_{2} \mathrm{Cl}_{2}\right)$, reported ${ }^{4}[\alpha]_{\mathrm{D}}+4.2\left(\mathrm{c} 6.5, \mathrm{CH}_{2} \mathrm{Cl}_{2}\right) ;{ }^{1} \mathrm{H} \mathrm{NMR}\left(300 \mathrm{MHz}, \mathrm{CDCl}_{3}\right)$ D $5.90(\mathrm{~m}, 1 \mathrm{H}), 5.02-$ $5.10(\mathrm{~m}, 2 \mathrm{H}), 4.06(\mathrm{~m}, 1.5 \mathrm{H}), 3.88(\mathrm{~m}, 1.5 \mathrm{H}), 2.38(\mathrm{~m}, 1 \mathrm{H}), 1.81(\mathrm{~m}, 1 \mathrm{H}), 1.55$ and 1.60 $(2 \mathrm{~s}, 6 \mathrm{H}), 1.51$ and $1.52(2 \mathrm{~s}, 9 \mathrm{H}), 1.09$ and $1.11(2 \mathrm{~d}, J=10.7 \mathrm{~Hz}, 3 \mathrm{H}), 1.06$ and 1.08 (2 $\mathrm{d}, J=7.0 \mathrm{~Hz}, 3 \mathrm{H}), 0.95$ and $0.96(2 \mathrm{~s}, 9 \mathrm{H}), 0.84$ and $0.86(2 \mathrm{~d}, J=6.7 \mathrm{~Hz}, 3 \mathrm{H}), 0.10$ and $0.11(2 \mathrm{~s}, 6 \mathrm{H})$.

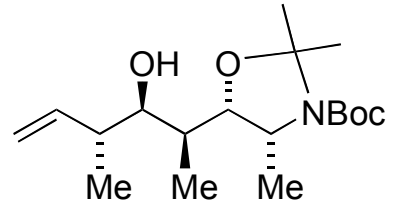

$(2 R, 3 S, 4 S, 5 R, 6 R)-(-)-2-($ tert-Butoxycarbonylamido)-4,6dimethyl-7-hepten-3,5-diol Acetonide (21). To a solution of alkene $20(20 \mathrm{mg}, 0.045 \mathrm{mmol})$ in THF $(0.1 \mathrm{~mL})$ was added TBAF $(0.07 \mathrm{~mL}, 1 \mathrm{M}$ in THF, $0.07 \mathrm{mmol})$. Upon completion of the reaction, as judged by TLC analysis, the reaction was quenched with water and extracted with $\mathrm{Et}_{2} \mathrm{O}$. The $\mathrm{Et}_{2} \mathrm{O}$ layer was separated, dried over $\mathrm{MgSO}_{4}$, filtered, and concentrated to give an oil that was chromatographed on silica gel with 5:1 hexanes/EtOAc as eluant to afford $10 \mathrm{mg}(67 \%)$ of alcohol $\mathbf{2 0}$ as a white crystal: $\mathrm{mp}$ $132-138{ }^{\circ} \mathrm{C}$, reported ${ }^{4} \mathrm{mp} 138-140{ }^{\circ} \mathrm{C} ;[\propto]_{\mathrm{D}}{ }^{20}-3.5\left(c 1.0, \mathrm{CH}_{2} \mathrm{Cl}_{2}\right)$, reported ${ }^{4}[\alpha]_{\mathrm{D}}{ }^{24}-4.6$ (c $\left.1.0, \mathrm{CH}_{2} \mathrm{Cl}_{2}\right) ;{ }^{1} \mathrm{H}\left(300 \mathrm{MHz}, \mathrm{CDCl}_{3}\right)$ D $5.85(\mathrm{~m}, 1 \mathrm{H}), 5.05-5.20(\mathrm{~m}, 2 \mathrm{H}), 4.10(\mathrm{~m}$, $1.5 \mathrm{H}), 3.88(\mathrm{~m}, 0.5 \mathrm{H}), 3.65(\mathrm{~m}, 1 \mathrm{H}), 2.31(\mathrm{~m}, 1 \mathrm{H}), 1.91(\mathrm{~m}, 1 \mathrm{H}), 1.62(\mathrm{br} \mathrm{s}, 4 \mathrm{H}), 1.55$ and $1.58(2 \mathrm{~s}, 3 \mathrm{H}), 1.51$ and $1.52(2 \mathrm{~s}, 9 \mathrm{H}), 1.13$ and $1.17(2 \mathrm{~d}, J=6.1 \mathrm{~Hz}, 3 \mathrm{H}), 1.03$ and $1.05(2 \mathrm{~d}, J=6.8 \mathrm{~Hz}, 3 \mathrm{H}), 0.86$ and $0.88(2 \mathrm{~d}, J=6.8 \mathrm{~Hz}, 3 \mathrm{H})$. 
85

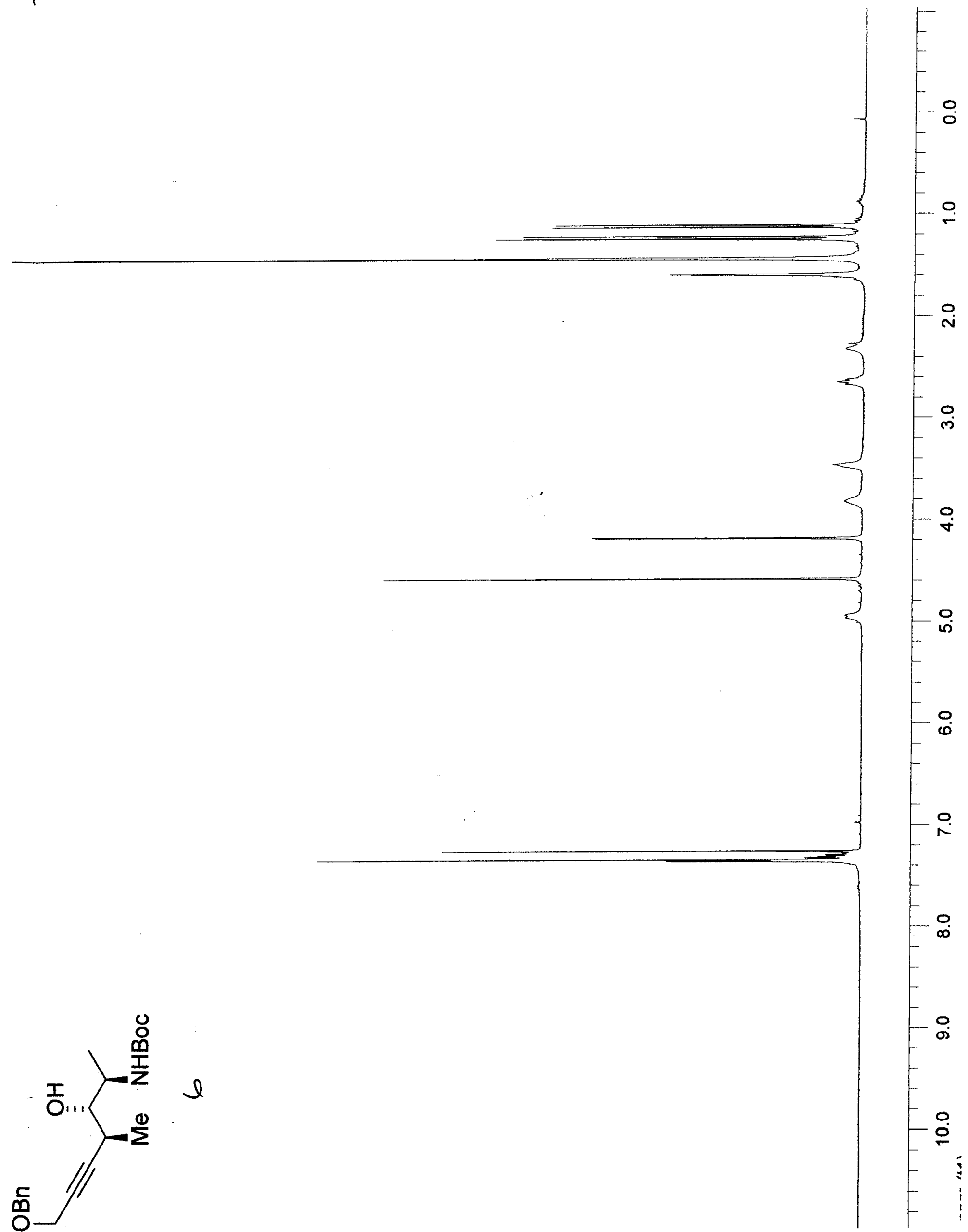


bst
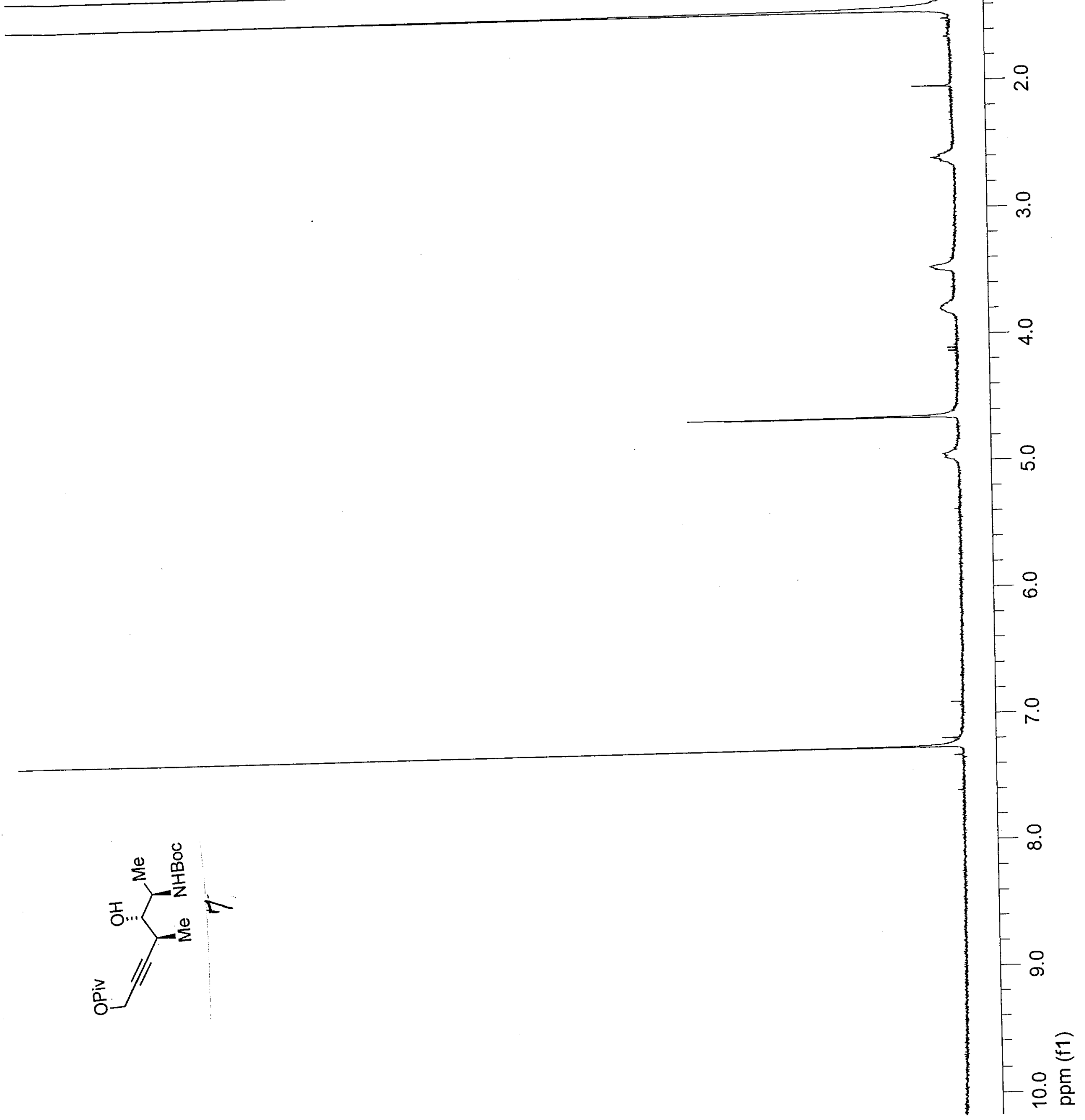
215

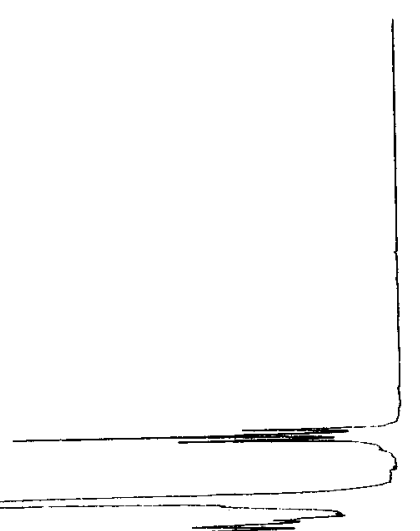

$\stackrel{0}{0}$
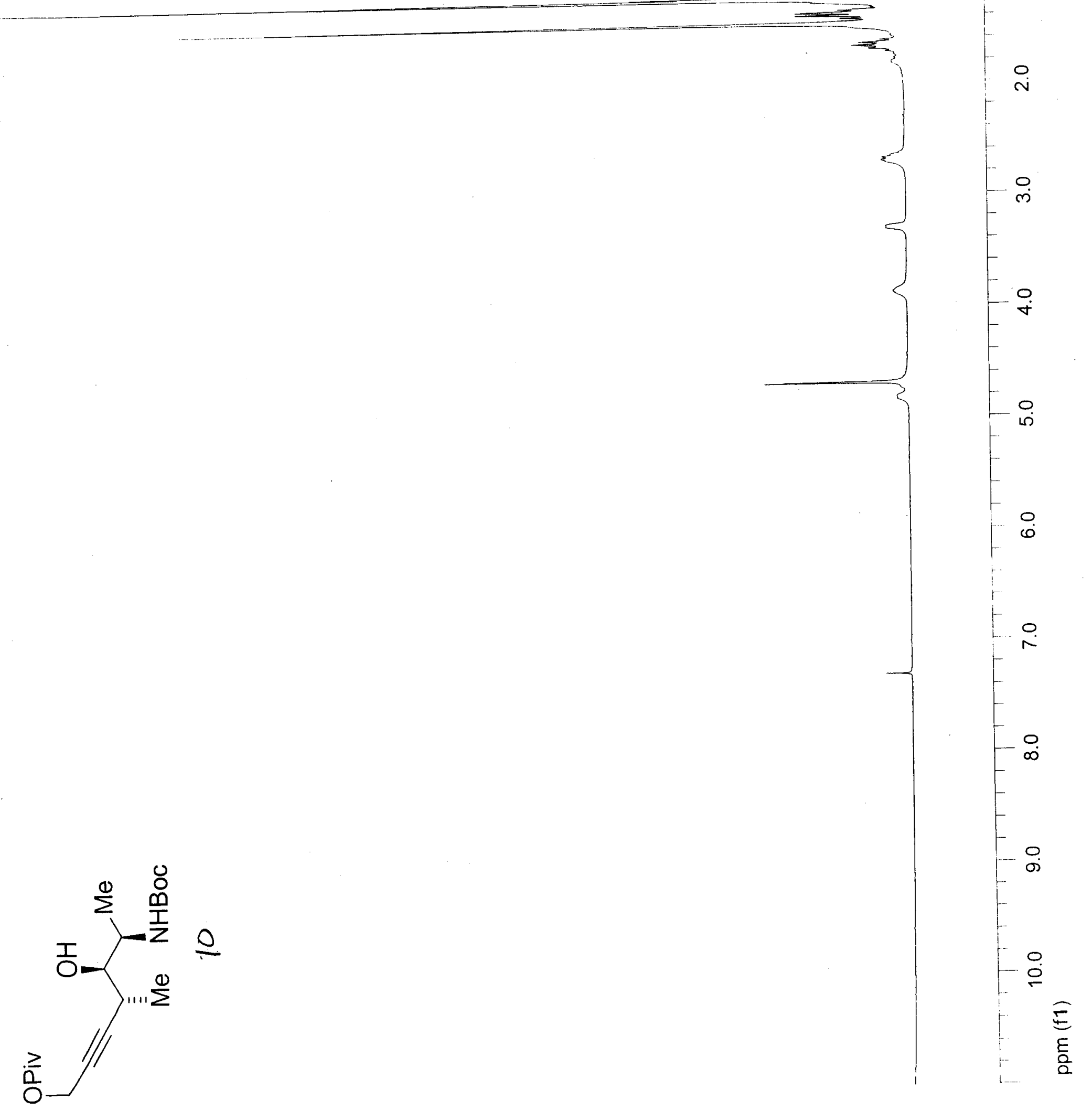
EIS
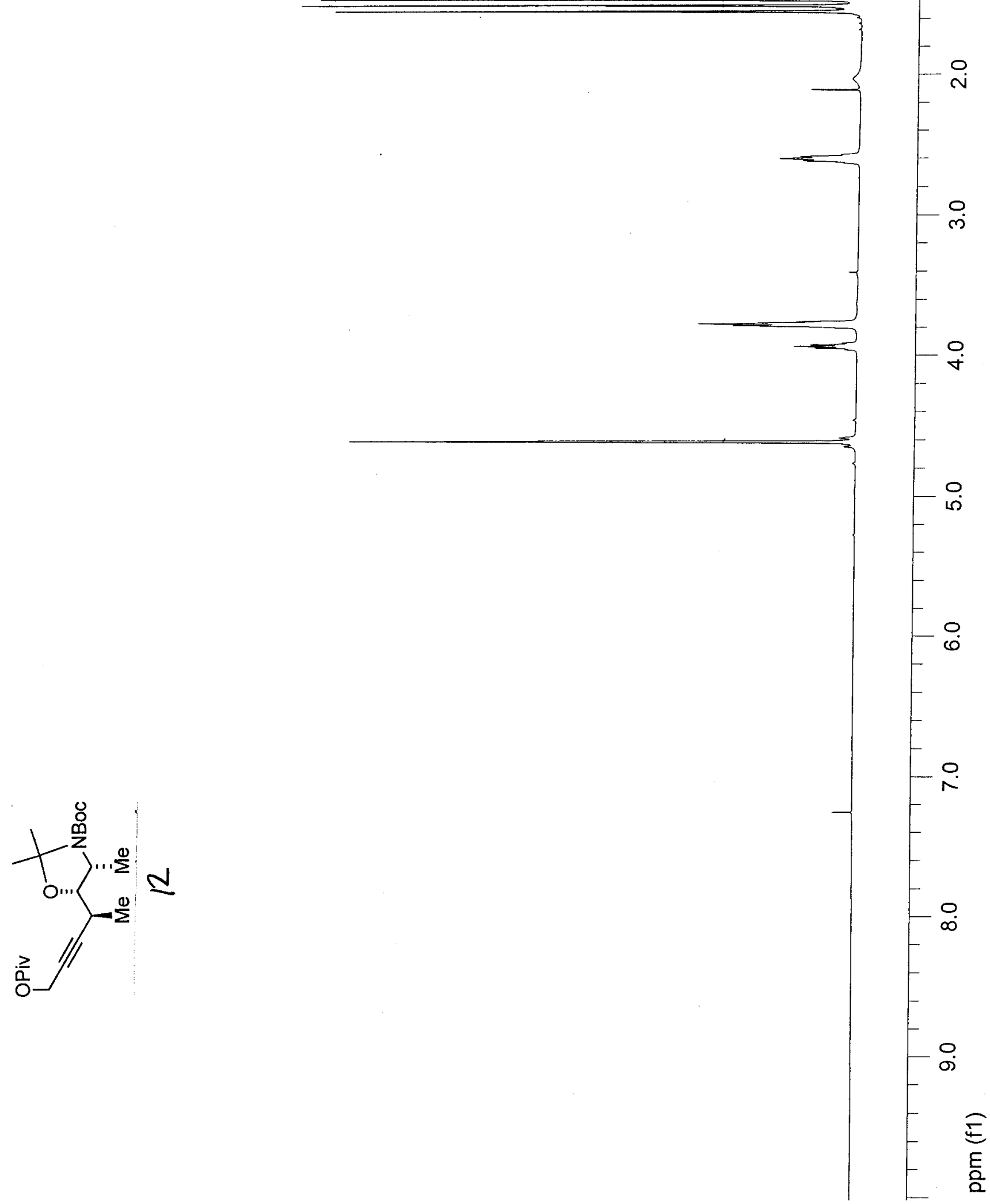
his

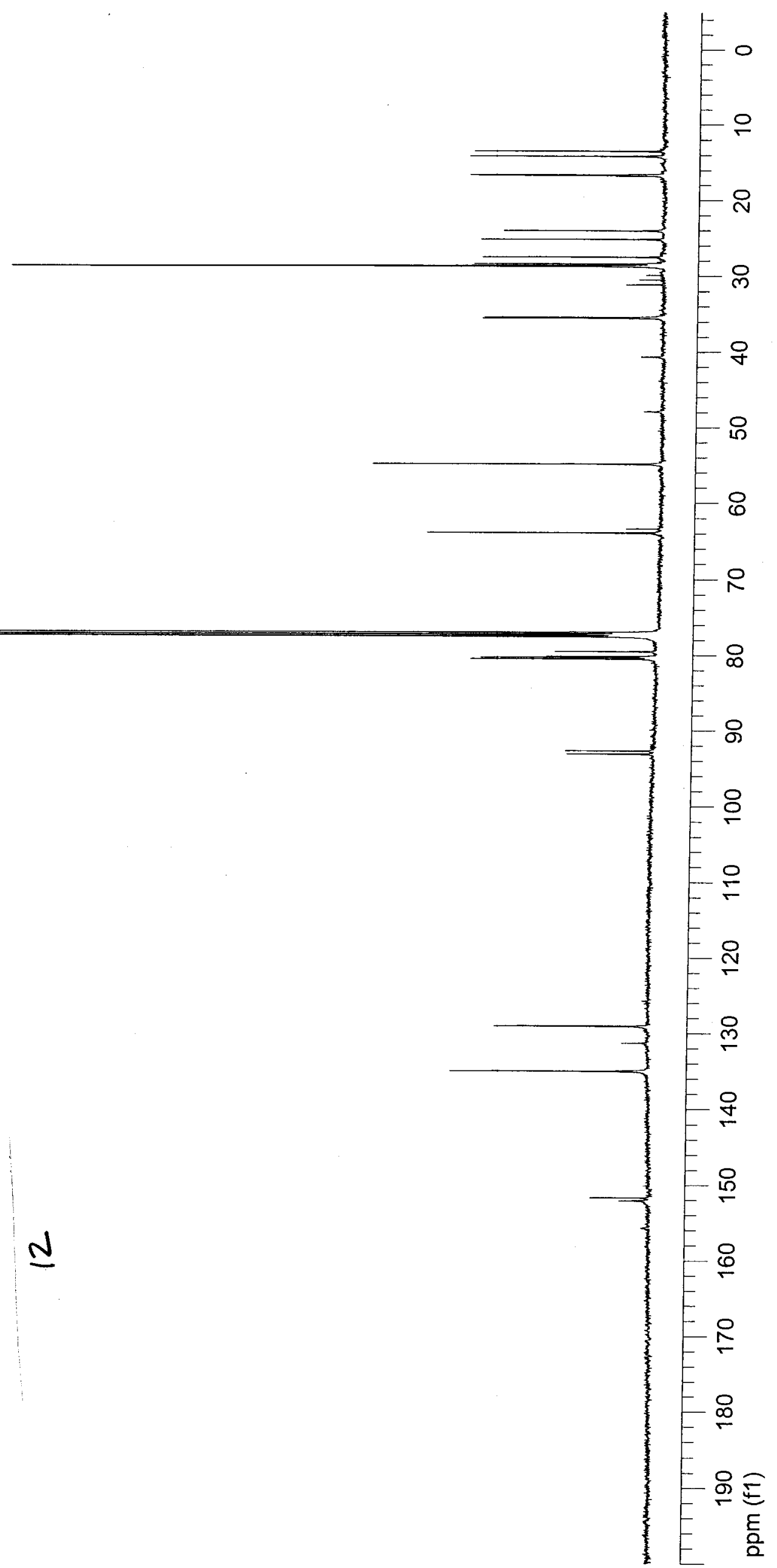


gis

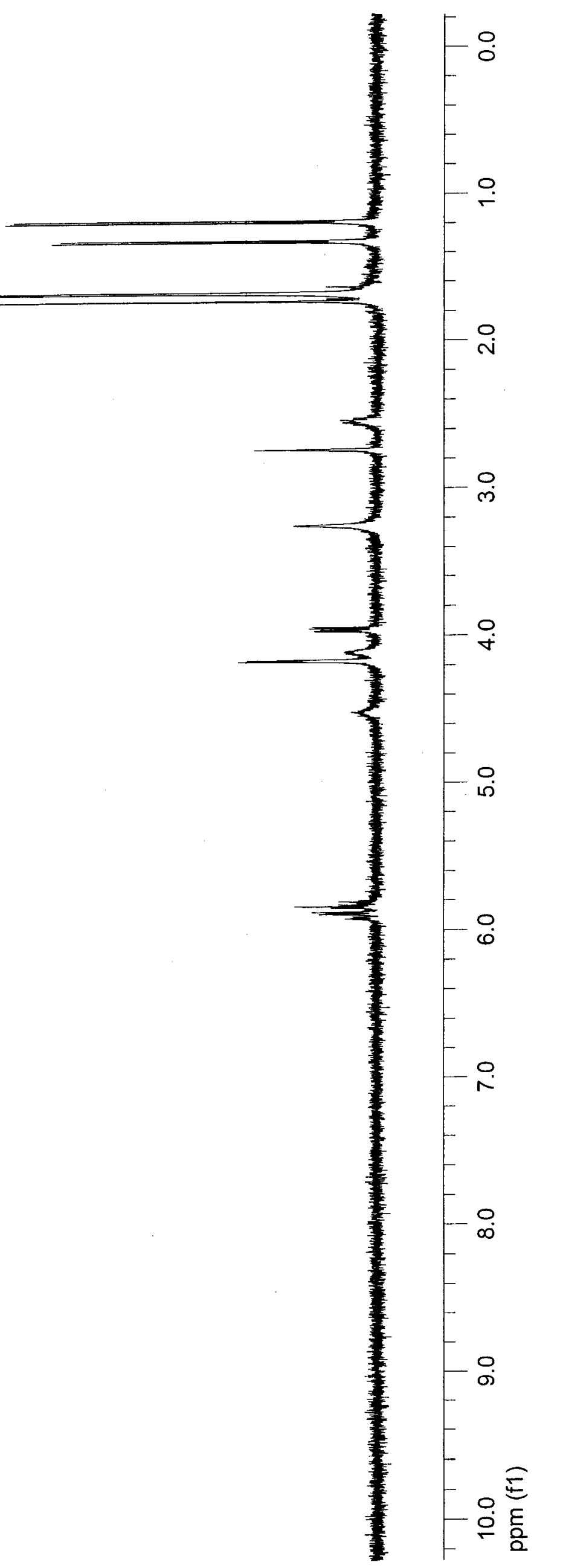


.915

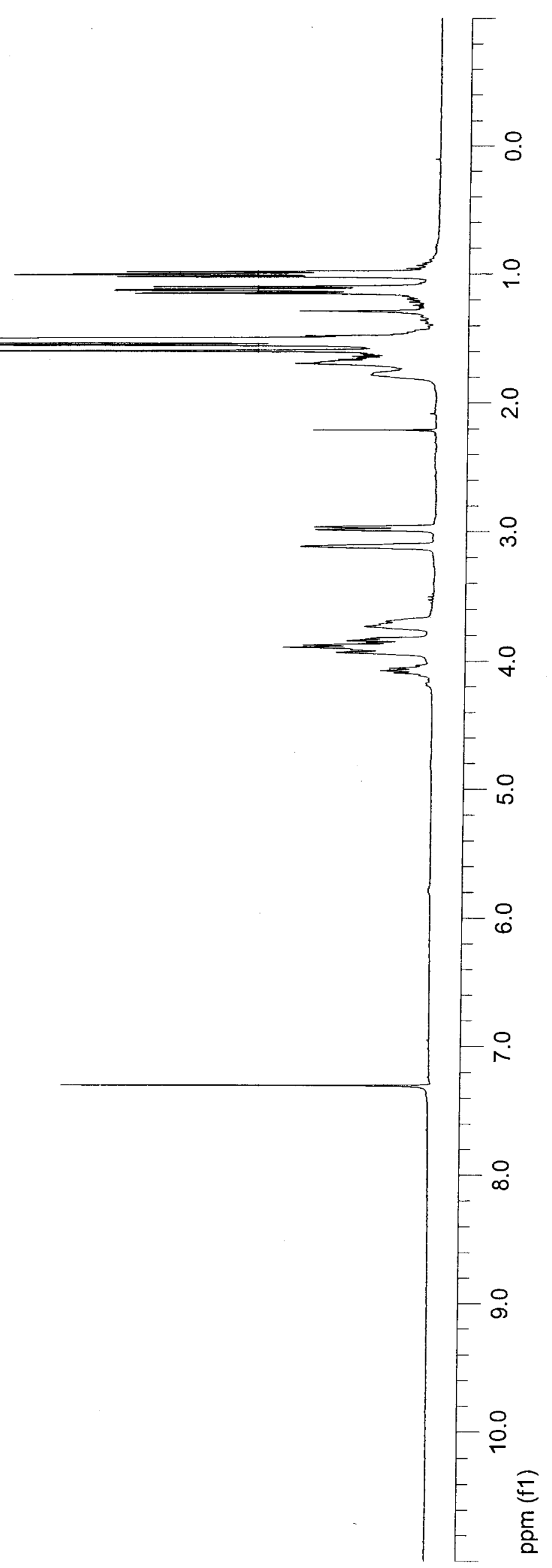


LIS
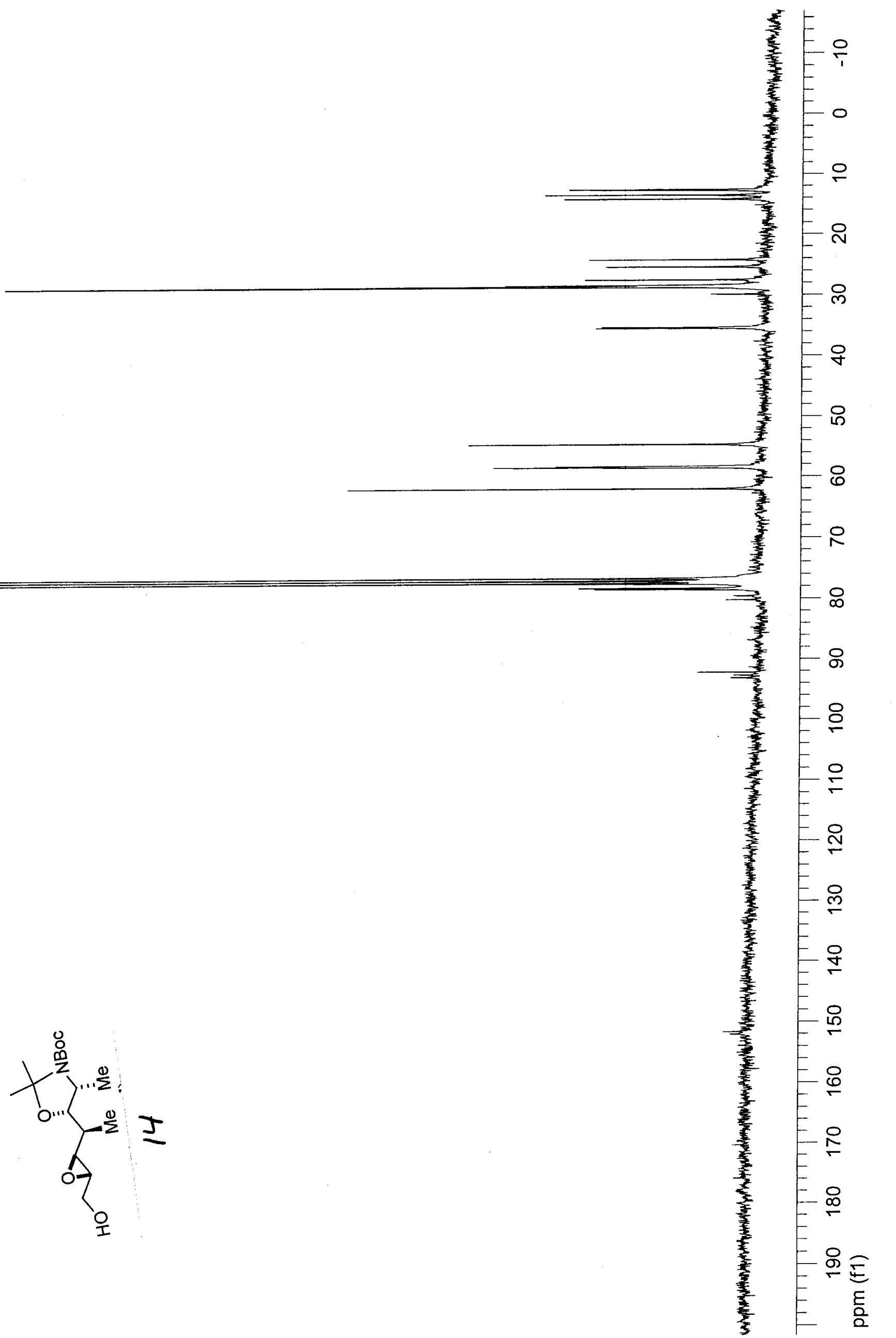
815

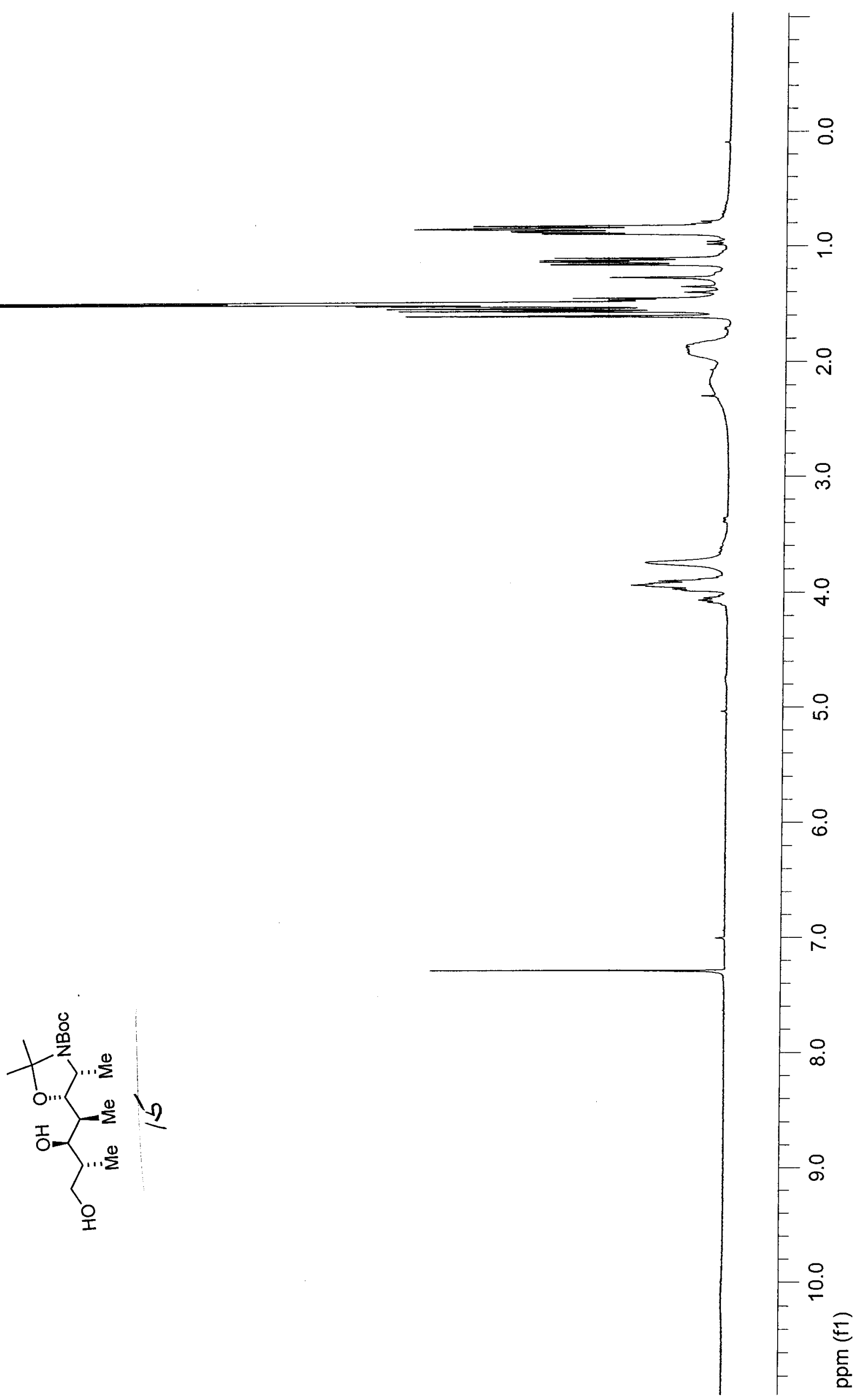


bIS

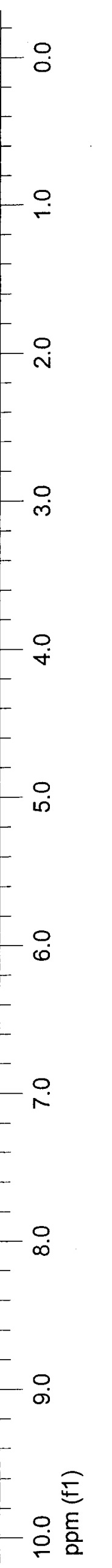




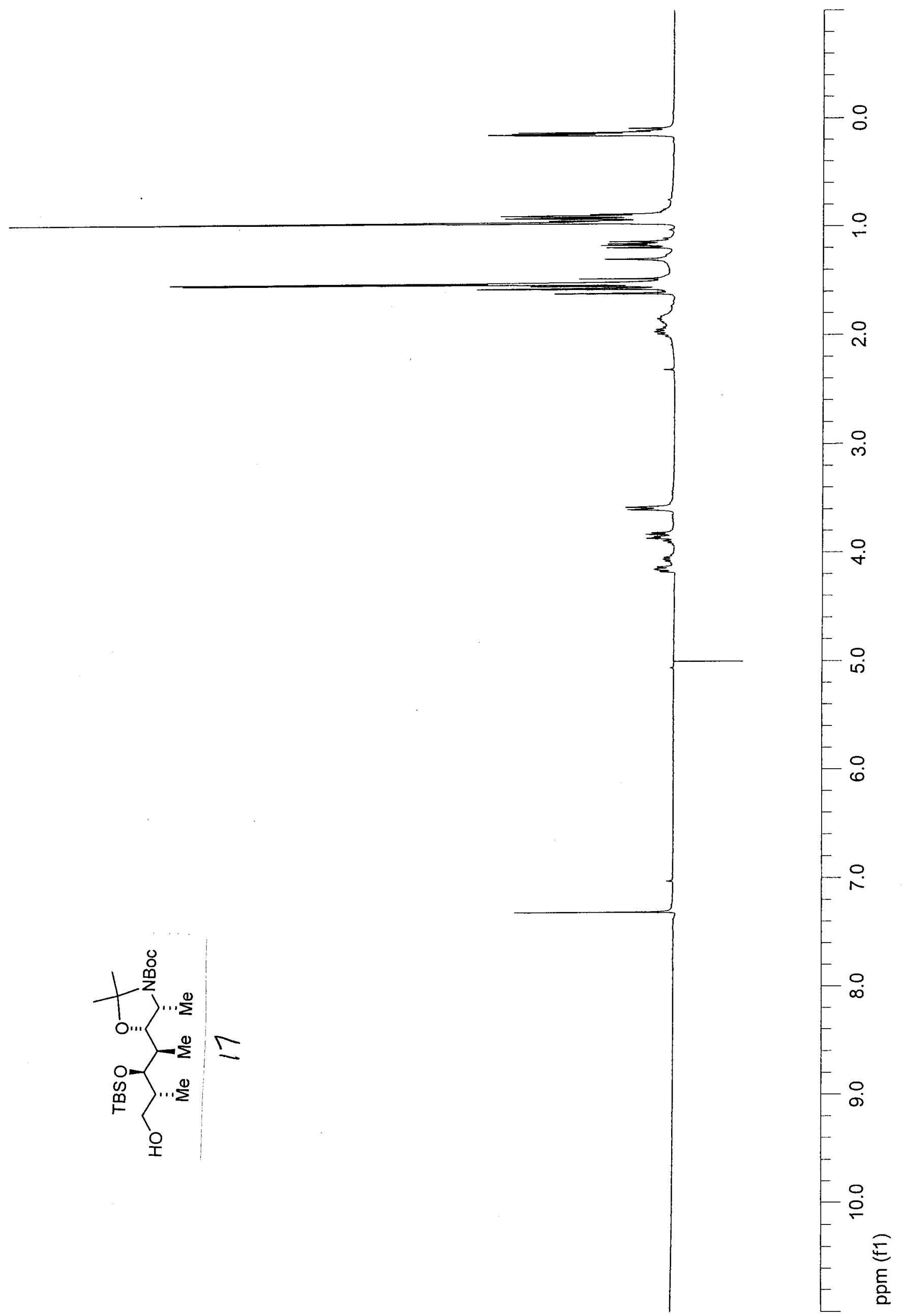


125

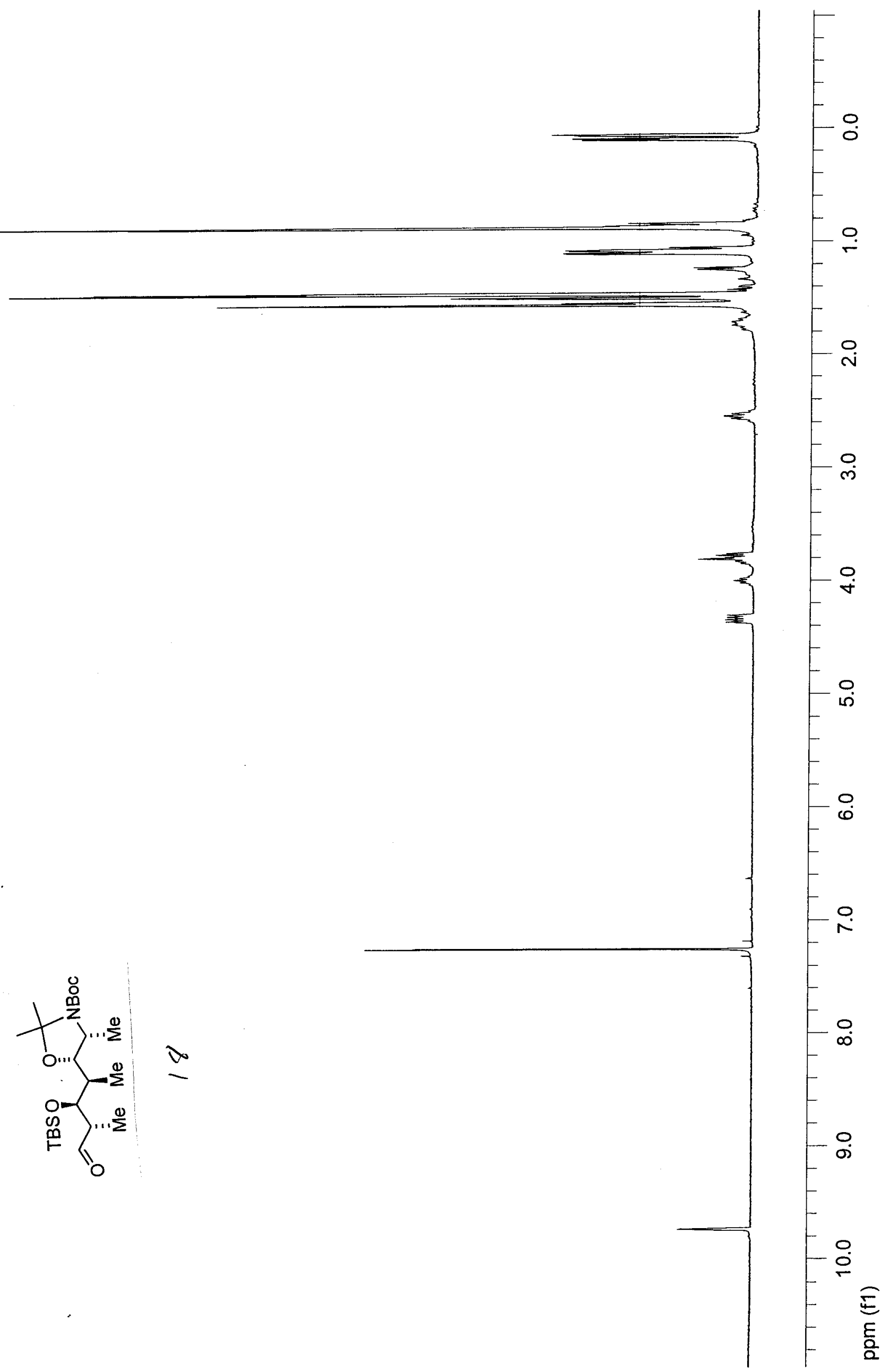




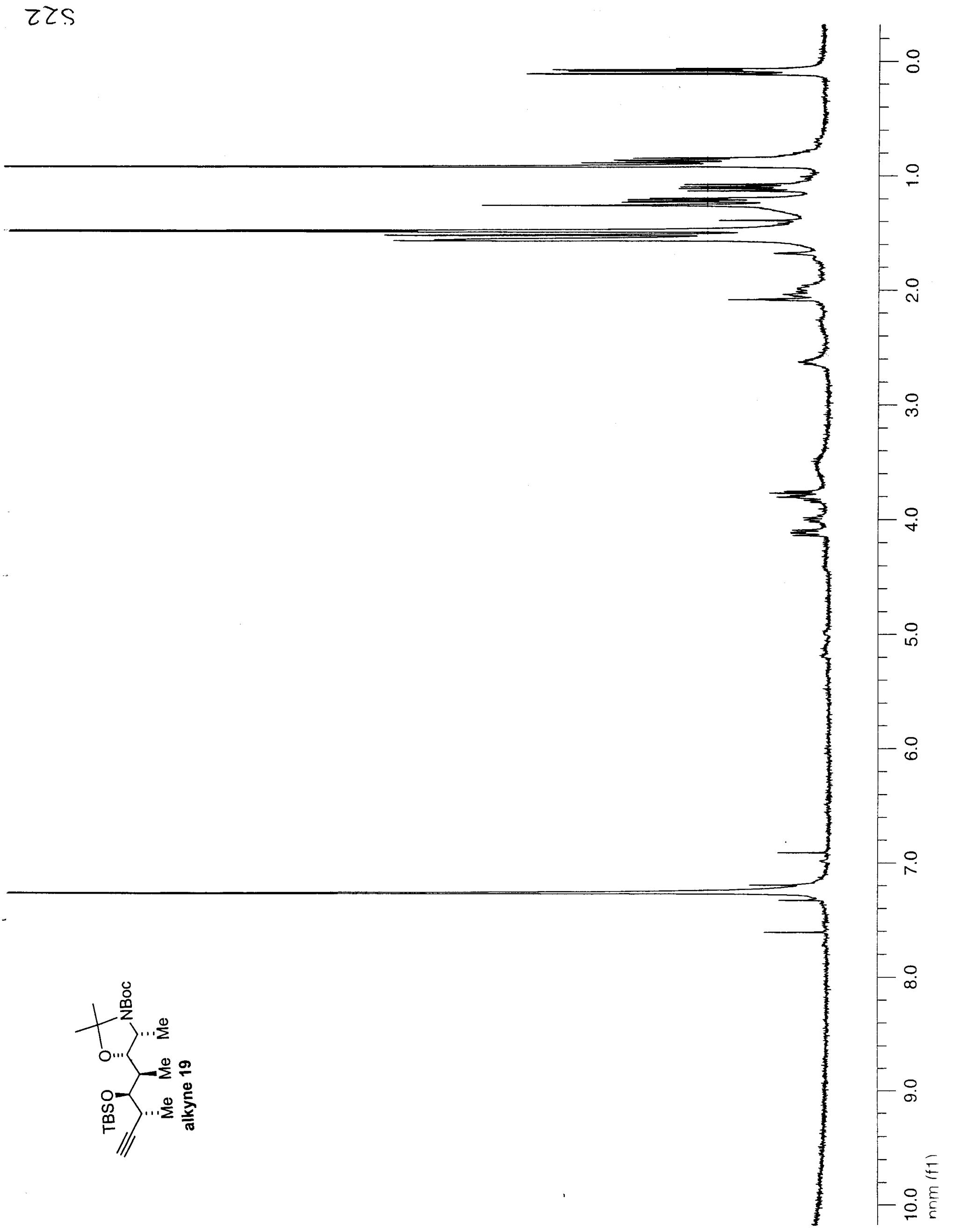


E2S
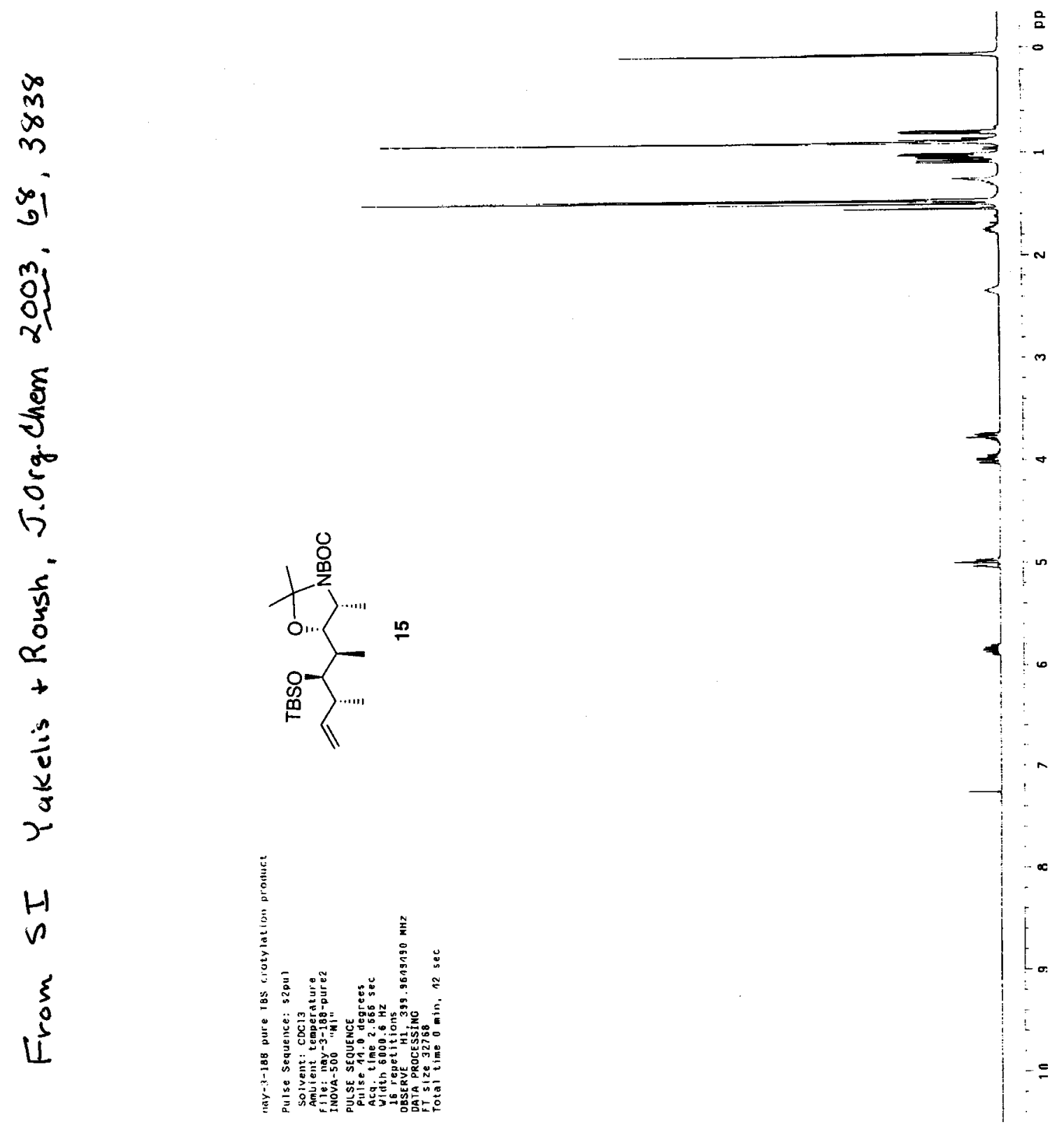


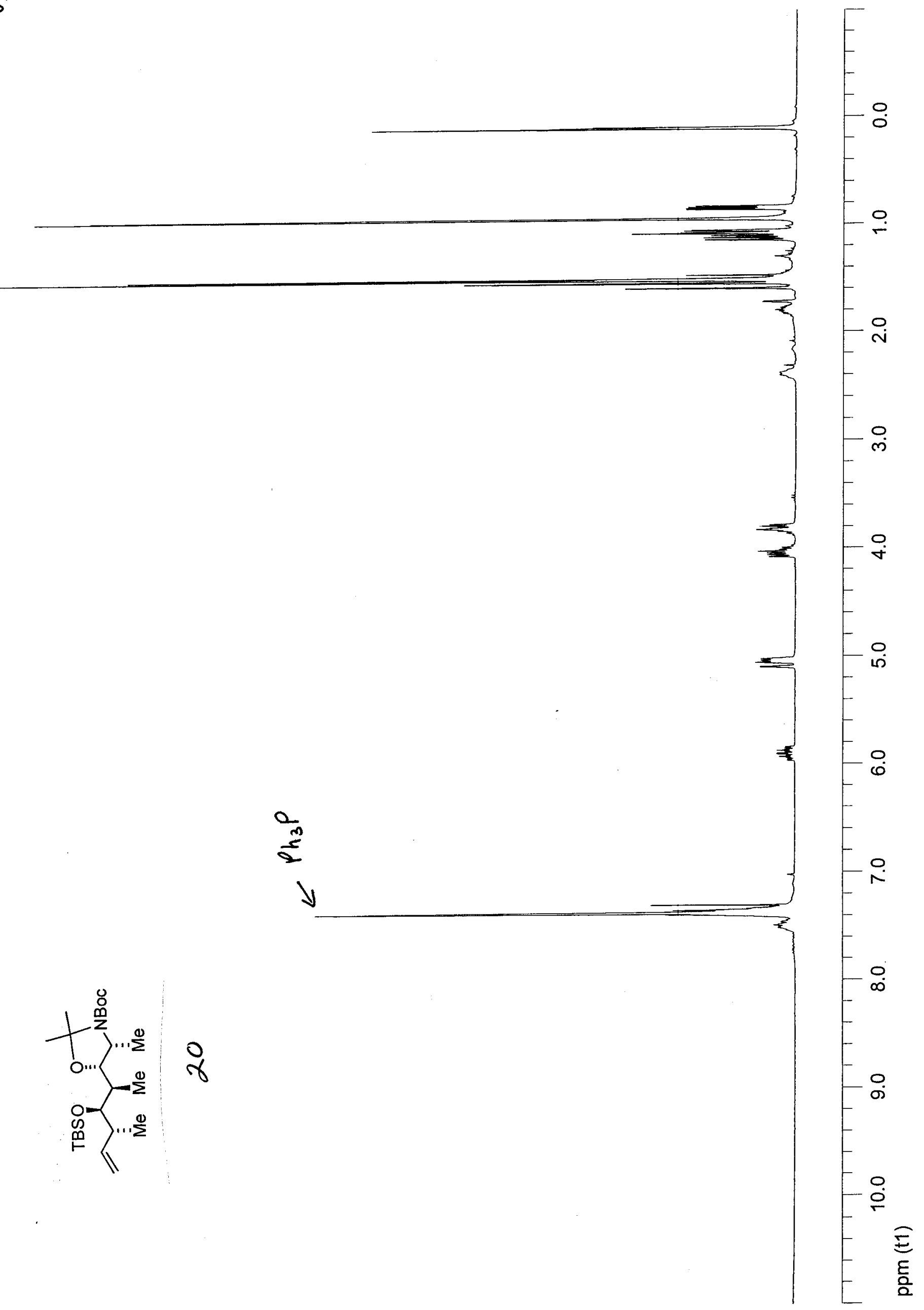


gies

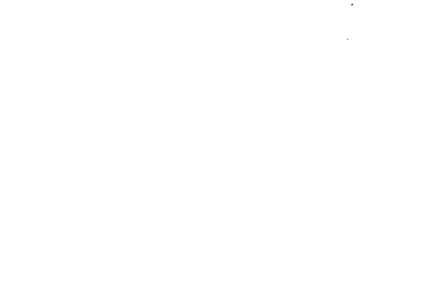

1

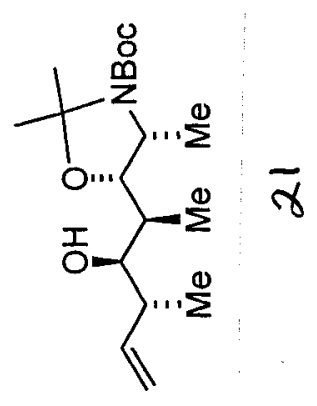

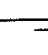

